\title{
Coat Protein and RNAs of Cole latent virus Are Not Present Within Chloroplasts of Chenopodium quinoa-Infected Cells*
}

\author{
Priscila Belintani \& José O. Gaspar \\ Departamento de Zoologia e Botânica, IBILCE/UNESP, 15054-000, São José do Rio Preto, SP, Brasil, \\ e-mail: gaspar@bot.ibilce.unesp.br
}

(Accepted for publication on 25/10/2002)

Corresponding author: José Osmar Gaspar

BELINTANI, P. \& GASPAR, J.O. Coat protein and RNAs of Cole latent virus are not present within chloroplasts of Chenopodium quinoainfected cells. Fitopatologia Brasileira 28:084-088. 2003.

\begin{abstract}
Cole latent virus (CoLV), genus Carlavirus, was studied by electron microscopy and biochemical approaches with respect both to the ultrastructure of the Chenopodium quinoa infected cells and to its association with chloroplasts. The CoLV was observed to be present as scattered particles interspersed with membranous vesicles and ribosomes or as dense masses of virus particles. These virus particles reacted by immunolabelling with a polyclonal antibody to CoLV. Morphologically, chloroplasts, mitochondria and nuclei appeared to be unaltered by virus infection and virus particles were not detected in these organelles. However, virus particle aggregates were frequently associated with the outer

membrane of chloroplasts and occasionally with peroxisomes. Chloroplasts were purified by Percoll gradient, and the coat protein and virus-associated RNAs were extracted and analyzed by Western and Northern blots respectively. Coat protein and CoLV-associated RNAs were not detected within this organelle. The results presented in this work indicate that the association CoLV/ chloroplasts, observed in the ultrastructural studies, might be a casual event in the host cell, and that the virus does not replicate inside the organelle.

Additional key words: Brassica, electron microscopy, Carlavirus, virus replication, plant virus.

\section{RESUMO}

Proteína capsidial e RNA do Cole latent virus não estão presentes dentro dos cloroplastos de células infetadas de Chenopodium quinoa

O vírus latente da couve (Cole latent virus, CoLV), gênero Carlavirus, foi estudado, por microscopia eletrônica de transmissão e técnicas bioquímicas, em relação à ultra-estrutura das células infetadas de Chenopodium quinoa, e de sua associação com os cloroplastos. O CoLV foi observado como partículas dispersas pelo citoplasma entremeadas com vesículas membranosas e ribossomos e/ou como densas massas de partículas. Estes partículas reagiram por imunomarcação com anti-soro policlonal para o CoLV. Morfologicamente, cloroplastos, mitocôndrias e núcleos mostraram-

se inalterados e partículas virais não foram encontradas dentro dessas organelas. Entretanto, agregados de partículas virais foram freqüentemente vistos em associação com a membrana externa dos cloroplastos e ocasionalmente com peroxissomos. Cloroplastos foram purificados em gradiente de Percoll e as proteínas e os RNA foram extraídos e analisados, respectivamente, por "Western blot" e "Northern blot". Proteína capsidial e RNA associados ao CoLV não foram detectados nessa organela. Os resultados aqui obtidos indicam que a associação CoLV/cloroplastos, observada nos estudos de microscopia eletrônica, é possivelmente um evento casual dentro da célula hospedeira e que o vírus não se multiplica dentro dessa organela.
\end{abstract}

\section{INTRODUCTION}

Cole latent virus (CoLV) was first detected in cole (Brassica oleracea L. var.acephala) in the State of São Paulo, Brazil (A. S. Costa, unpublished results). Based on its pathological and morphological characteristics (filamentous particles c. $650 \mathrm{~nm}$ in length), CoLV was considered to be a member of the genus Carlavirus (Kitajima et al., 1970; Brunt et al., 2000).

More recently, molecular evidence was obtained supporting the recognition of CoLV as a distinct species of the Carlavirus genus (Belintani et al., 2002). The CoLV

* Part of the Dr. thesis of the first author. Universidade Estadual Paulista. (2001) genomic RNA of $8,3 \mathrm{~Kb}$ is polyadenylated. Two unencapsidated polyadenilated subgenomic RNAs (2.6 and $1.3 \mathrm{~Kb}$ ) and three double-stranded RNAs (8.3, 2.6 and 1.3 $\mathrm{Kbp}$ ) are produced in CoLV-infected plants. By using a carlavirus specific primer and a CoLV cDNA, a 3'-terminus fragment was amplified, cloned and sequenced. It had the highest homology with the carlavirus Potato virus $M(62 \%)$. However, these two viruses differ in some biological properties, including host range, indicating that they are distinct viruses.

Thin sections of cole root and leaf infected by CoLV, showed the occurrence of particle aggregates and vesiculated areas in the cytoplasm in most of the cells, except within the tracheids and sieve tubes (Kitajima et al., 1970). 
Coat protein and RNAs of Cole latent virus are not...

Electron microscopic examination of infected tissues has demonstrated that carlaviruses are confined to the cytoplasm of epidermis and mesophyll cells and less frequently found in phloem (Tu \& Hiruki, 1970; Thongmeearkon et al., 1984; Weintraub, 1993), xylem (Rudzinska-Langwald, 1990) and occasionally within plasmodesmata (Weintraub, 1993). Tissues infected by carlaviruses undergo cytological modifications involving the presence of abundant individual virus particles and/or aggregates and membranous inclusions (Koenig 1982). No virus particles were found in chloroplasts, mitochondria and nuclei. However, virus particles were detected closely associated and often attached to the membrane of chloroplasts, mitochondria, tonoplasts and nuclei (Tu \& Hiruki, 1970; De Bokx \& Waterreus, 1971; Bos \& RubioHuertos, 1972; Rubio-Huertos \& Bos, 1973; Brunt et al., 1976; Kuschki et al., 1978; Hearon, 1982; RudzinskaLangwald, 1990).

In the present study, we report the ultrastructure of the cells in CoLV-incited local lesions inChenopodium quinoa Willd and a biochemical investigation into the association of CoLV and the chloroplasts of infected cells.

\section{MATERIAL AND METHODS}

\section{Plant and virus}

The CoLV isolate utilized in this work was the same described by Belintani \& Gaspar (2002). C. quinoa plants were mechanically inoculated with CoLV suspended in 0.02 $\mathrm{M}$ phosphate buffer $\mathrm{pH} 7.2$ containing $0.02 \mathrm{M}$ sodium sulphite and Celite at $0.05 \mathrm{~g} / \mathrm{ml}$. Plants were kept in a greenhouse at $28^{\circ} \mathrm{C}$. Infected plants produced local lesions about eight days after inoculation.

\section{Fixation and embedding}

Local lesions induced by CoLV and samples of uninfected $C$. quinoa leaves were processed as described by Espinha \& Gaspar (1999). Ultrathin sections (60 nm) were cut on a Reichert Ultracut ultramicrotome using a diamond knife and mounted on Butvar-coated grids. Thin-sections were post stained with uranyl acetate and lead citrate and examined in a Zeiss EM 906 electron microscope at $80 \mathrm{kV}$. For immunolabelling, the protocol described by Gaspar et al. (1990) was followed. The anti-CoLV polyclonal antiserum (a donation of Dr. Avelino Rodrigues de Oliveira, UNICAMP) was crossabsorbed with proteins prepared from healthy $C$. quinoa (Fasseas et al., 1989).

\section{Chloroplast isolation}

Chloroplasts from healthy leaves and from areas containing the local lesions induced by CoLV were purified following Más et al. (2000) with modifications. Tissues were gently homogenized at $4{ }^{\circ} \mathrm{C}$ with two volumes of grinding buffer [Tris. $\mathrm{HCl} 0.05 \mathrm{M} \mathrm{pH} 7.2$ containing DTT $0.001 \mathrm{M}$, EGTA $0.002 \mathrm{M}$, BSA $0.1 \%(\mathrm{w} / \mathrm{v})$ and Sorbitol $0.35 \mathrm{M}$ ], filtrated sequentially through nylon filters $(80 \mu \mathrm{m}$ and 20 $\mu \mathrm{m})$ and then centrifuged at $1000 \mathrm{~g}$ for $10 \mathrm{~min}$ at $4{ }^{\circ} \mathrm{C}$. The pellet was resuspended in grinding buffer and the chloroplasts purified in a gradient (40\% and $85 \%$ ) of Percoll centrifuged at $13000 \mathrm{~g}$ for $7 \mathrm{~min}$ at $4{ }^{\circ} \mathrm{C}$. The chloroplasts sedimented at the $40-85 \%$ interface were collected, diluted with four volumes of the grinding buffer and centrifuged at $1000 \mathrm{~g}$ for $10 \mathrm{~min}$ at $4{ }^{\circ} \mathrm{C}$. After three cycles of washing with grinding buffer, the final pellet containing the purified chloroplasts was resuspended and the quality of the chloroplasts was determined by phase contrast light microscopy. Proteins and RNAs were extracted and analyzed as described below.

\section{Protein and nucleic acid extraction}

Proteins and RNAs were extracted from chloroplasts using the commercial product TRIzol as recommended by the manufacturer (Gibco BRL). The proteins were resuspended in sodium dodecyl sulfate (SDS) $1 \%$ and the RNAs in DEPC-treated water and stored at $-70^{\circ} \mathrm{C}$.

\section{Protein analysis}

Proteins were resolved by SDS-PAGE and then Western transferred to nitrocellulose membrane by electro blotting in a Mini Transfer Cell at $100 \mathrm{~V}$ for $2 \mathrm{~h}$ in Tris. $\mathrm{HCl}$

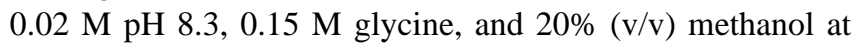
room temperature, following the manufacturer instructions (Bio Rad). Membranes were blocked (BSA 3\%) and incubated with the primary antibodies (anti-CoLV and anti-Ribulose bifosfate carboxylase) diluted 1:1,000 in PBS-Tween-20 buffer. The antigen-antibody complexes were detected with alkaline phosphatase-conjugated goat anti-rabbit IgG (Sigma), using bromochloroindolyl phosphate (BCIP) and nitroblue tetrazolium (NBT) as a substrate.

\section{cDNA probe synthesis and RNA analysis}

The CoLV was purified following the protocol described by Belintani et al. (2002). A cDNA probe was prepared by incorporation of digoxigenin (DIG-dUTP; Boehringer Mannheim) using $500 \mathrm{ng}$ of RNA isolated from purified CoLV as a template, $10 \mathrm{pmol}$ oligo $\mathrm{d}(\mathrm{T})$ as a primer and 40 unid. of reverse transcriptase (Superscript II RNase $\mathrm{H}^{-}$; Gibco BRL). The RNAs were electrophoresed in formamide/formaldehyde agarose gel, visualized by ethidium bromide staining and Northern transferred under vacuum to nylon membrane. The nucleic acids were fixed under UV radiation at $150 \mathrm{~mJ}$ oule and hybridized with the CoLV probe at $50{ }^{\circ} \mathrm{C}$ for $20 \mathrm{~h}$. The membranes were washed in SSC $2 \mathrm{x}$ containing $\operatorname{SDS} 0.1 \%$ ( $2 \times 5 \mathrm{~min}$; room temperature) and SSC 1x with SDS $1 \%\left(2 \times 15 \mathrm{~min} ; 68^{\circ} \mathrm{C}\right)$ and used for chemiluminescent detection with the DIG luminescent detection kit following the manufacturer instructions (Amersham Pharmacia).

\section{RESULTS AND DISCUSSION}

The cytopathology caused by CoLV in local lesions induced in $C$. quinoa was shown to be very similar to that induced by the same virus in systemically infected cole 
(Kitajima et al., 1970) and by other members of the Carlavirus genus (Tu \& Hiruki, 1970; Brunt et al, 1976; Hearon, 1982; Koenig, 1982, Thongmeearkon et al., 1984; Weintraub, 1993; Rudzinska-Langwald, 1990). The CoLV can be seen in cytoplasm as scattered particles interspersed with membranous vesicles and ribosomes (Figure 1A) a common feature found in cells infected by many plant viruses and considered to be the site of virus multiplication (Martelli \& Russo, 1977). The CoLV can also be seen as dense accumulations where the particles were present as more or less parallel arrays which, in cross section, sometimes reveal a para-crystalline arrangement (Figure 1B) where each particle, 12-14 $\mathrm{nm}$ in diameter, is surrounded by six equi-distant virions (Figure $1 \mathrm{~B}$, inset). An axial canal (internal dark ring), about $5 \mathrm{~nm}$ in diameter, can also be seen in each virus particle. The virus particles reacted by immuno-labelling with a polyclonal antibody to CoLV (Figure 2).

Morphologically, chloroplasts, mitochondria and

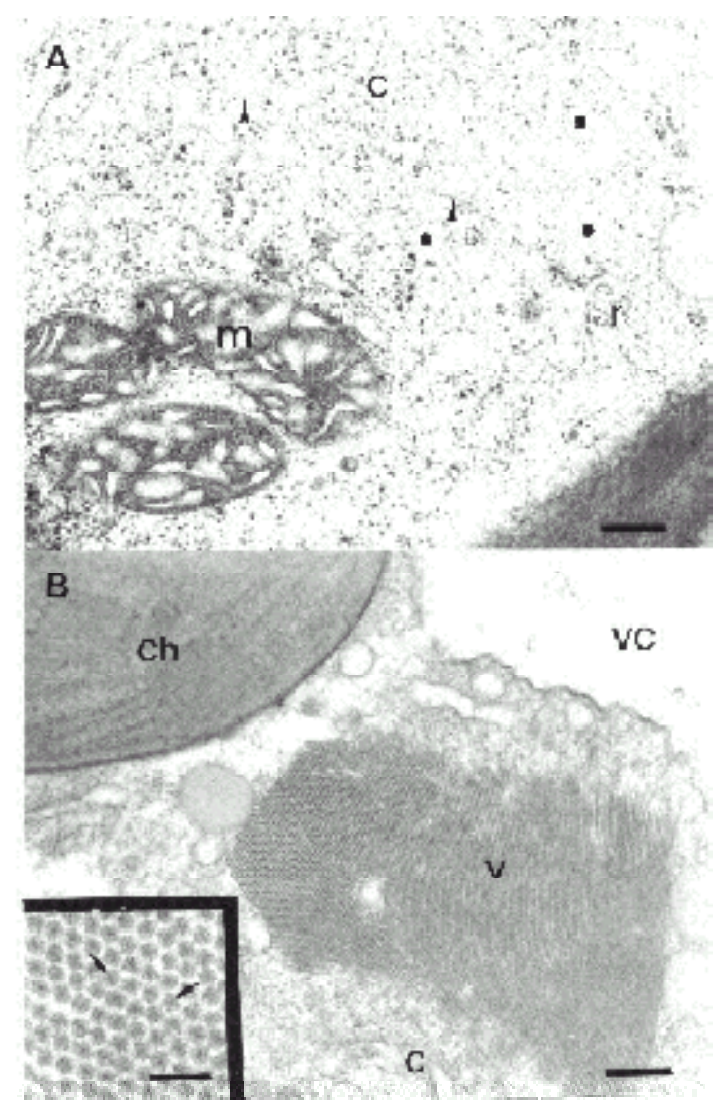

FIG. 1 - Electron micrographs showing (A) scattered particles (arrows) interspersed with membranous vesicles (*) and ribosomes (r) in the cytoplasm (c) and (B) Cole latent virus inclusion (v) showing, on the left, a paracrystalline arrangement. The inset presents details of each particle surrounded by six equi-distant virions. Axial canals (internal dark rings) are shown (arrows). (m) mitochondria; (vc) vacuole; (ch) chloroplast. Figure 1A, B, Bar $=200 \mathrm{~nm}$; Inset, Bar $=50 \mathrm{~nm}$.

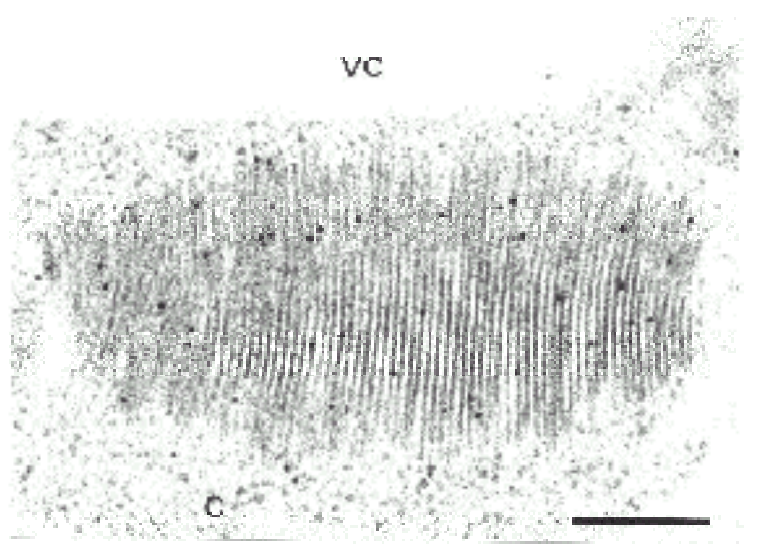

FIG. 2 - Leaf section probed with anti-CoLV antiserum and labeled with colloidal gold. Essentially only virus particles are labeled. (c) cytoplasm; (vc) vacuole. Bar $=200 \mathrm{~nm}$.

nuclei appeared to be unaltered by CoLV infection and virus particles or aggregates were not found inside these organelles. However, virus particle aggregates were frequently associated with the outer membrane of the chloroplasts (Figure 3A) and occasionally with peroxisomes (Figure $3 \mathrm{~B}$ ). It has been shown

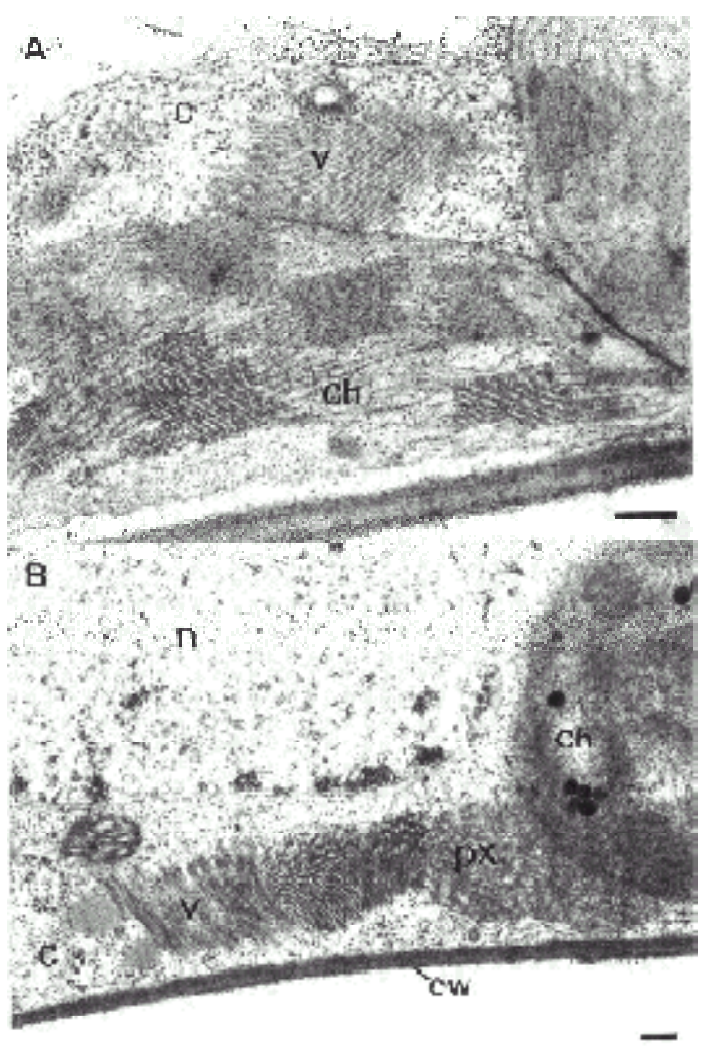

FIG. 3 - Electron micrographs showing Cole latent virus particle aggregates (v) associated with (A) the outer membrane of the chloroplast (ch) and (B) with peroxisome (px). (c) cytoplasm; (n) nucleus; (cw) cell wall of Chenopodium quinoa. Figure $3 \mathrm{~A}$, B, Bar $=200 \mathrm{~nm}$. 
Coat protein and RNAs of Cole latent virus are not...

that species of the Carlavirus genus have close external association with cellular organelles, principally with chloroplasts (Kitajima et al., 1970; Tu \& Hiruki, 1971; Hiruki \& Shukla, 1973; Hiruki \& Tu, 1972), but the significance of these interactions, if any, has yet to be determined.

In order to better investigate the association of CoLV with the chloroplasts of infected cells, these organelles were isolated on Percoll gradients and the proteins and RNAs extracted and analyzed. When proteins were separated by SDS-PAGE (Figure 4A), Western transferred to nitrocellulose membranes and incubated with the CoLV-specific antiserum (Figure 4B), no reaction was observed with the chloroplast fractions obtained from healthy and CoLV-infected leaves. However, a clear reaction was seen with the CoLV-coat protein used as a positive control. The same chloroplast samples reacted positively (Figure 4C) with an antiserum to Ribulose bisfosfate carboxylase (Rubisco) used as a marker for the integrity of the isolated chloroplasts. Gel electrophoresis and Northern hybridization with the CoLV-specific cDNA probe produced no hybridization signal with the nucleic acids extracted from chloroplasts of healthy and CoLV-infected leaves, but, rather, a strong signal with the CoLV-genomic RNA used as a control (Figure 5). Similar results were also obtained with chloroplasts isolated from cole systemically infected by CoLV (data not shown).

Foster \& Mills (1991) have proposed that the presence of canonical prokaryotic Shine Dalgarno sequences (which could be involved in chloroplast ribosome binding) within carlaviruses genome and the association of virus particles with chloroplasts may indicate that this organelle has a role in the infection process of carlaviruses. The Shine Dalgarno

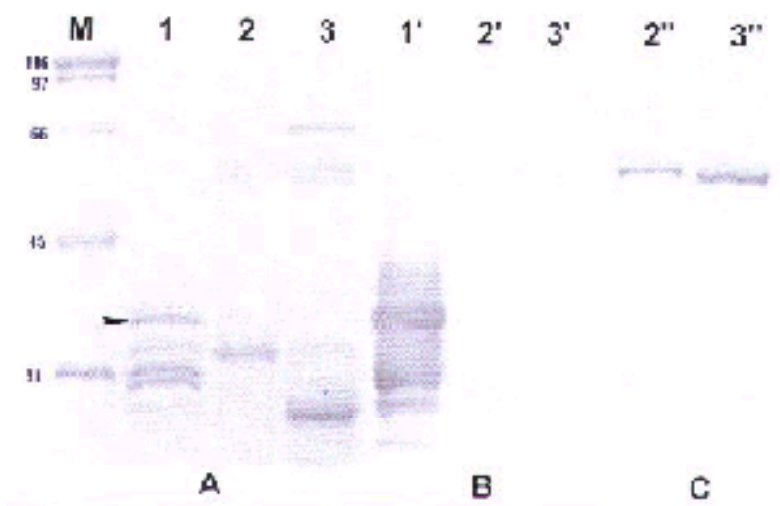

FIG. 4 - Analysis of the proteins extracted from chloroplasts of Chenopodium quinoa. A. SDS-polyacrylamide gel. $B$ and $C$, Western blot of a gel similar to $A$ incubated with anti-CoLV and anti-Rubisco, respectively. $M$, molecular weight markers in $\mathrm{kDa}$; 1 and 1', coat protein of purified Cole latent virus; 2, 2', and 2', proteins from chloroplasts of CoLVinfected leaves; $3,3^{\prime}$, and $3^{\prime}$ ', proteins from chloroplasts of healthy leaves. The polypeptides, other than CoLV-coat protein (arrow), are, probably, products of degradation.

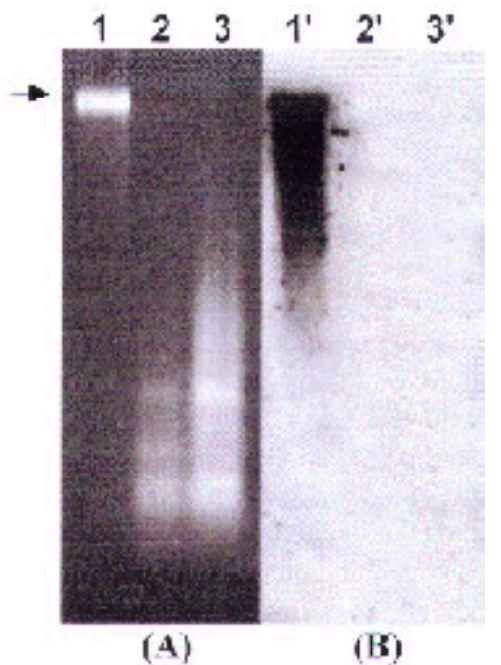

FIG. 5 - Analysis of the RNAs extracted from chloroplasts of Chenopodium quinoa. A, $1.2 \%$ agarose gel stained with ethidium bromide. B, Northern blot of a gel similar to A hybridized with a cDNA probe specific to Cole latent virus. 1, 1', RNA extracted from CoLV-purified particles (arrow); 2,2', RNAs from chloroplasts of CoLV-infected leaves; 3,3', RNAs from chloroplasts of healthy leaves.

sequences are located upstream from the proposed initiation codons (ATG) of the carlavirus $25 \mathrm{kDa}$ and coat protein genes. As the coat protein molecules are normally synthesized in large quantities in the infected cells, one should expect a large production of coat protein inside the chloroplasts, enough to be detected by the Western blot technique. However, the results described in the present work enable us to conclude that the coat protein and RNAs associated with CoLV are not present inside the chloroplasts of infected cells, indicating that the external association of CoLV with chloroplasts, observed in ultrastructural studies, might be a casual event in the host cell and that the virus does not replicate within these organelles. Thus, the role of the Shine Dalgarno sequences in the carlavirus genome, if any, is yet to be determined.

It has been demonstrated that chloroplasts have been associated with the replication of some viruses (Schoeltz \& Zaitlin, 1989; de Graaf et al., 1993), but it seems more probable that the multiplication site of CoLV is the cytoplasm and in association with membranous vesicles (Figure 1), which seems to be a general characteristic of those viruses with single-stranded RNA and positive polarity (de Zoeten et al., 1974; Reinke \& de Zoeten, 1991; Más et al., 2000).

\section{ACKNOWLEDGMENTS}

This work was supported by Fundação de Amparo à Pesquisa do Estado de São Paulo (FAPESP). P. B. is grateful to the Conselho Nacional de Desenvolvimento Científico e Tecnológico (CNPq) for the scholarship. We thank Dr. Avelino 
Rodrigues de Oliveira (UNICAMP) for the CoLV antiserum.

\section{LITERATURE CITED}

BELINTANI, P., GASPAR, J.O., TARGON, M.L.P.N. \& MACHADO, M.A. Evidence supporting the recognition of Cole latent virus as a distinct Carlavirus. Journal of Phytopathology 150:330-333. 2002.

BOS, L. \& RUBIO-HUERTOS, M. Light and electron microscopy of pea streak virus in crude sap and tissues of pea (Pisum sativum). Netherlands Journal of Plant Pathology 78:247-257. 1972.

BRUNT, A.A., FOSTER, G.D., YU, S., MOROZOV, S.Y. \& ZAVRIEV, S.K. Carlavirus. In: Van Regenmortel, M.H.V., Fauquet, C.M., Bishop, D.H.L., Carstens, E.B., Estes, M.K., Lemon, S.M., Maniloff, J., Mayo, M.A., McGeoch, D.J., Pringle, C.R. \& Wickner, R.B. (Eds) Virus Taxonomy. Seventh Report of the International Committee on Taxonomy of Viruses. Academic Press, San Diego, USA. 2000. pp. 969-975.

BRUNT, A.A., STACE-SMITH, R. \& LEUNG, E. Cytological evidence supporting the inclusion of poplar mosaic virus in the carlavirus group of plant viruses. Intervirology 7:303-308. 1976.

DE BOKX, J.A. \& WATERREUS, H.A.J.I. Electron microscopy of plant tissues infected with potato viruses A and S. Netherlands Journal of Plant Pathology 77:106-112. 1971.

DE GRAAF, M., COSCOY, L. \& JASPARS, E.M.J. Localization and biochemical characterization of alfalfa mosaic virus replication complexes. Virology 194:878-881. 1993.

DE ZOETEN, G.A., ASSINK, A.M. \& VAN KAMMEN, A. Association of cowpea mosaic virus-induced double-stranded RNA with a cytopathological structure in infected cells. Virology 88:105107. 1974.

ESPINHA, L.M. \& GASPAR, J.O. Subcellular localization of the coat protein in tobacco cells infected by cucumber mosaic virus isolated from Catharanthus roseus. Cytobios 100:119-126. 1999.

FASSEAS, C., ROBERTS, I.M. \& MURANT, A.F. Immunogold localization of parsnip yellow fleck virus particle antigen in thin sections of plant cells. Journal of General Virology 70:2741-2749. 1989.

FOSTER, G.D. \& MILLS, P.R. Occurrence of chloroplast ribosome recognition sites within conserved elements of the RNA genomes of carlaviruses. FEBS Letters 280:341-343. 1991.

GASPAR, J.O., DUNIGAN, D.D. \& ZAITLIN, M. In vivo localization of ubiquitin in tobacco mosaic virus infected and uninfected tobacco cells. Molecular Plant-Microbe Interactions 3:182-187. 1990.
HEARON, S.S. A carlavirus from Kalanchoe blossfeldiana. Phytopathology 72:838-844. 1982.

HIRUKI, C. \& SHUKLA, P. Intracellular location of potato virus S in leaf tissue of Chenopodium quinoa. Canadian Journal of Botany 51:1699-1702. 1973.

HIRUKI, C. \& TU, J.C. Light and electron microscopy of potato virus $M$ lesions and marginal tissue in red kidney bean. Phytopathology 62:77-85. 1972.

KITAJIMA, E.W., CAMARGO, I.J.B. \& COSTA, A.S. Morfologia e aspectos intracelulares do vírus latente da couve. Bragantia 29:181190. 1970.

KOENIG, R. Carlavirus group. CMI/AAB Descriptions of Plant Viruses $\mathrm{N}^{\circ}$ 259. 1982.

KUSCHKI, G.H., KOENIG, R., DUVEL, D. \& KUHNE, H. Helenium virus $S$ and $\mathrm{Y}$ - two new viruses from commercially grown Helenium hybrids. Phytopathology 68:1407-1411. 1978.

MARTELLI, G.P. \& RUSSO, M. Plant virus inclusion bodies. Advances in Virus Research 21:175-254. 1977.

MÁS, P., SÁNCHEZ-PINA, A., BALSALOBRE, J.M. \& PALLÁS, V. Subcellular localisation of cherry leaf roll virus coat protein and genomic RNAs in tobacco leaves. Plant Science 153:113-124. 2000. REINKE, K.J. \& DE ZOETEN, G.A. In situ localisation of plant viral gene products. Phytopathology 81:1306-1314. 1991.

RUBIO-HUERTOS, M. \& BOS, L. Light and electron microscopy of red clover vein mosaic virus in pea (Pisum sativum). Netherlands Journal of Plant Pathology 79:94-103. 1973.

RUDZINSKA-LANGWALD, A. Cytological changes in phloem parenchyma cells of Solanum rostratum (Dunal.) related to the replication of potato virus M (PVM). Acta Society of Botany Poloniae 59:45-53. 1990.

SCHOELTZ, J.E. \& ZAITLIN, M. Tobacco mosaic virus enters chloroplasts in vivo. Proceedings of the National Academy of Science USA. 86:4496-4500. 1989.

THONGMEEARKON, P., HONDA, Y., IWAKI, M. \& DEEMA, N. Ultrastructure of soybean leaf cells infected with cowpea mild mottle virus. Journal of Phytopathology 109:74-79. 1984.

TU, J.C. \& HIRUKI, C. Ultrastructure of potato infected with potato virus M. Virology 42:238-242. 1970.

TU, J.C. \& HIRUKI, C. Electron microscopy of cell wall thickening in local lesions of potato virus $M$ infected red kidney bean. Phytopathology 61:862-868. 1971.

WEINTRAUB, M. A carlavirus and a rhabdovirus infecting Lonicera $x$ brownii cv. Dropmore Scarlet in western Canada. Journal of Phytopathology 139:57-67. 1993. 